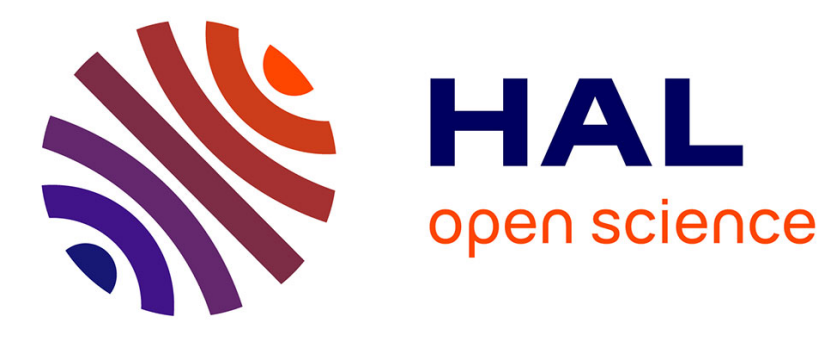

\title{
To Embrace Career Decision Making in STEM Education
}

\author{
Nathalie Chelin, Greta Matthiasdottir, Yann Serreau, Luis Tudela, Siegfried \\ Rouvrais, Katie Jordan
}

\section{- To cite this version:}

Nathalie Chelin, Greta Matthiasdottir, Yann Serreau, Luis Tudela, Siegfried Rouvrais, et al.. To Embrace Career Decision Making in STEM Education. 11th International Conference on Education and New Learning Technologies, Jul 2019, Palma de Mallorca, Spain. pp.3058 - 3066, 10.21125/edulearn.2019.0827 . hal-02221338

\section{HAL Id: hal-02221338 \\ https://hal.science/hal-02221338}

Submitted on 1 Aug 2019

HAL is a multi-disciplinary open access archive for the deposit and dissemination of scientific research documents, whether they are published or not. The documents may come from teaching and research institutions in France or abroad, or from public or private research centers.
L'archive ouverte pluridisciplinaire HAL, est destinée au dépôt et à la diffusion de documents scientifiques de niveau recherche, publiés ou non, émanant des établissements d'enseignement et de recherche français ou étrangers, des laboratoires publics ou privés. 


\title{
TO EMBRACE CAREER DECISION MAKING IN STEM EDUCATION
}

\author{
Nathalie Chelin ${ }^{1}$, Gréta Matthíasdóttir ${ }^{2}$, Yann Serreau ${ }^{3}$, Lluis Tudela ${ }^{4}$, Siegfried \\ Rouvrais ${ }^{1}$, and Katie Jordan ${ }^{5}$ \\ ${ }^{1}$ IMT Atlantique, UBL, Graduate School of Engineering (FRANCE) \\ ${ }^{2}$ Reykjavik University (ICELAND) \\ ${ }^{3}$ CESI Group (FRANCE) \\ ${ }^{4}$ Fundació Universitat Empresa de les Illes Balears (SPAIN) \\ ${ }^{5}$ City of Glasgow College (SCOTLAND)
}

\begin{abstract}
Choosing a career is often a challenge, especially in new professional contexts, as seen today with the fourth industrial revolution for students in STEM (Science, Technology, Engineering, and Maths). Students require not only technical and academic skills but also skills in making decisions in complex situations and environments. Higher and Vocational Education students in STEM must embrace the reality of career decision making from the beginning of their curriculum. They must be self-aware of their weaknesses, their personal qualities to improve and the strengths that will allow them to face with greater success a world / professional environment that are increasingly volatile, uncertain, complex, and ambiguous (VUCA). Institutions of higher education and vocational education (VET) can assist students to make appropriate decisions in their professional career in VUCA situations. They must not only train students to learn technical and academic skills but also enable these young people to be well prepared in the face of an unpredictable professional world.
\end{abstract}

This paper presents some results of the DAhoy European project. It recalls the landmarks that are keys for leading one's decisions and actions making of the students and the different models for career management and counselling that address career decision-making in the domain. It overviews how STEM students should approach career decision making, and how higher and VET institutions can contribute to strengthening their decision-making skills and their judgment thanks to active teaching and learning activities. Some collaborative card games operated in four different European institutions show how to confront learners to different career situations and help them to improve their knowledge and decision skills.

Keywords: Career - orientation - professional project - decision - VUCA - first job - serious games, card games.

Educational Trends and Best Practice Contributions, Workplace Training and Employability Issues, Tutoring and Coaching, 21st Century Skills, STEM.

\section{INTRODUCTION}

The business world is changing more quickly than ever before, rapidly evolving markets, regulations and technologies make it difficult to predict future. The world is changing at a rapid pace and is becoming increasingly Volatile, Uncertain, Complex, and Ambiguous (VUCA) [1]. Business and industry sectors have recognized a growing need to enhance skills that enable young professionals to deal with VUCA situations, i.e. with unexpected scenarios and events such as; financial crisis, company reorganization, unstable software systems, or even natural disasters. A good decision at the right time not only relies on knowledge. It is also a question of skills. International companies confirm that decision qualities and skills are now very attractive to companies and they will surely become even more important in the future. Robin Karvo, Human Resources Consultant at Nokia France, recalls that 'today's business world is changing more quickly than ever before: rapidly evolving markets, regulations, and technologies make it hard to see very far into the future. We all work in increasingly volatile, uncertain, complex and ambiguous business environments' [2]. 
Nowadays, education is about facilitating students to develop a reliable compass and the navigation skills to find their own way through the VUCA world. Embedding decision skills into a curriculum is essential for future STEM professionals. They must be ready for unforeseen VUCA situations. This is now the responsibility of HE (Higher Education) and VET institutions: training future graduates, through transferable skills approach, so that they can turn knowledge into skills and provide into well rounded personal and professional answer when faced with ever-changing circumstances. It is of major importance for schools and universities to train future workers to be flexible, agile, adaptable, and resourceful life-long learners. Academic courses and hands-on training like internships and apprenticeships can help learners to manage and even thrive in VUCA situations. Isabelle Leclerc, international Human Resources manager from Amadeus indicates that 'mental and emotional agility will help junior professionals to adapt to the fluctuating business conditions.' A variety of experiences - both inside and outside the classroom - will help them develop the skills they will need to respond calmly and quickly to new situations.

Students must learn to be employable and to manage their own career [3], whilst making decisions regarding their professional life. STEM qualifications greatly facilitate first job offers, but how to teach students to better identify and manage career directions? How can higher education institutions and STEM educators prepare upstream learners for an unpredictable professional future, reinforce their judgment \& career decision-making skills? With the majority career's being open all, how to decide with equality, fair judgement and impartiality? How to discover the deep motivation behind the choice of first job? How to improve students' ability to actively construct a realistic personal and professional life balance. Thanks to the European DAhoy project investigations since 2017 on decision-making skills [4], this paper proposes to elaborate on the career decision making in STEM along three areas: (i) career choice models, (ii) card games, used identify leaners' strengths and reinforce learners' career decision skills, and (iii) VUCA characteristics perception of some STEM students. These topics help to identify students' perceptions and misconceptions of profession, skills, and career paths, enabling them to actively manage their own career path, build their future professional identity, plan proactively their future career. In addition to the learners benefits the higher education (HE) and vocational education \& training (VET) communities will be prompted to investigate and research integrating career decision making into the curriculum.

\section{FOUNDATIONS OF CAREER MANAGEMENT AND COUNSELLING}

Graduate STEM qualifications greatly facilitate successful applications for first job offers and open wide career possibilities in many economic fields where graduate managers and engineers may often exercise their potential as leaders and future decision makers. However incoming STEM students do not necessarily have a fixed professional ideal [3], they may have limited knowledge of the 'working world', do not always identify and understand the career spectrum, or struggle to identify career directions. Thus, their career choice is often still undecided, even close to the end of their studies. Some students struggle to identify career directions. Young graduates should take care of their early professional pathway as attractive offers may have sometimes undesirable consequences in the medium terms. However, uncertainty and indecision often result from student appraisal of the career kaleidoscope [3]. Some struggle to identify career directions and therefore need time before feeling committed and being operational within their curriculum and first jobs.

Motivation factors for the first job were analysed recently in some HE or VET institutions for STEM $[5,6]$. Student respondents mostly considered the interest in the job as a primary criterion, followed by job well-being and matching their core personal values. Other criteria mentioned match across to the 'career kaleidoscope' such as; team members, type of mission or projects, position or title, location (local/international), training options and lifelong learning, time and style management, facility of career changes to face up difficulties, etc. The decision- 
making process should be seen as continuous process among which desires, experiences, capacities and situations would influence the person and allow them to react in the changing environment. A few key points can be highlighted as landmarks in leading decisions and actions. These landmarks are connected rather than separate entities, and include, identifying desires and their links to deep motivation, representation about the situation and about one's action into the situation (based on efficacy feeling, individual values, a perception of one's personal qualities and competencies, experiences, a.s.o.). During the action, many decisions, at different levels will be taken and the person is always adjusting their energy and risk level, to meet their goals and targets. [7].

\subsection{Some models for career decision making}

Several models addressing career decision making and learning exist. The Holland Codes or the Holland Occupational Themes (RIASEC), is a theory of careers and vocational choice based upon personality types [8]. This theory is the best known and most widely researched. There are six basic types of work environment: Realistic, Investigative, Artistic, Social, Enterprising, and Conventional (cf. Fig. 1). People consider environments where they can use their skills, abilities and values. For example, Investigative types are more looking for a problem-solving environment. People who choose to work in an environment similar to their personality type are more likely to be satisfied. A hexagonal model (figure 1) shows the relationship between the personality types and environments. Choosing a career or education program that fits Holland personality should be a vital step toward career well-being and success-job satisfaction.

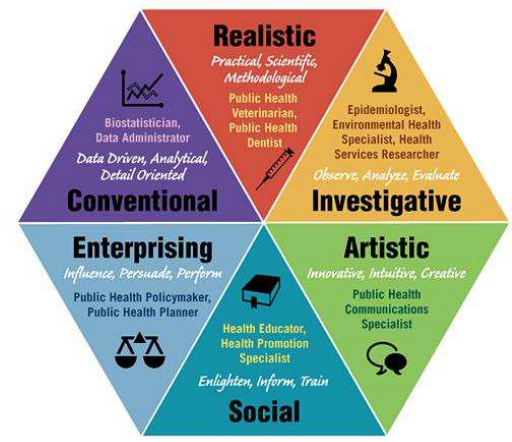

Figure 1. Holland types

Other models address the career learning issues, such as the DOTS model which is a four stages model of career planning [9]. It has 4 stages: (i) Decision Making - being able to weigh up personal factors to make a sound plan - career exploration and decision making, (ii) Opportunity Awareness - Knowledge of opportunities and the ability to research these, (iii) Transition Learning - Understanding of how to seek and secure opportunities - , and (iv) Self Awareness (self-assessment and the ability to identify and articulate motivations, skills and personality as they affect career plans). However, this is not always a logical order to achieve the aims of career planning, even facing VUCA circumstances. For example, in the ACIP model, there are four essential steps should be followed to make a critical decision, (i) A stands for ALTERNATIVES. When making an important decision, look at all your choices. Ask yourself, 'Are there any other ways I can solve this problem?', (ii) C stands for CONSEQUENCES. Once you have narrowed down your choices to those that look best, weigh the pros and cons of each, (iii) I stands for INFORMATION. Search for new information about each option you are considering, and (iv) P means PLANS. Make detailed plans for (a) how you will carry out your decision, and (b) what you will do if one of the negative consequences that you thought of under ' $\mathrm{C}$ ' occurs [10]. All of these learning models are a basis on which to base career decision making for education. 


\subsection{European focus in STEM education}

As recalled in a blog post the 21 January 2019 in an Interview with Julie Miller Vick, 'Providing career counselling and career education for graduate students is an innovation of the last 20 years" (cf. Stanford University Tomorrow's Professor Postings Msg. \#1691 Pioneer of Grad Career Development). In Europe, several educational projects now face this issue. For example, the Network for Innovation in Career Guidance and Counselling in Europe (NICE) (http://www.nice-network.eu/) worked on a model developed by an academic network of 40 higher education institutions in 28 European countries, which is funded with financial support from the European Commission under the Lifelong Learning Program. It includes one Curriculum framework that is composed of 9 modules. The modules systemize numerous ideas for the definition of learning outcomes in terms of competencies and resources required (Generic Professional Competences, Career Education, Career Assessment and Information, Career Counselling, Career Service Management, Social Systems Interventions). In Sweden and engineering education, Professionalism with soft skills and emotional intelligence to prepare for professional life is studied [11]. In the Netherlands, the 'Bridging the gap' project [12] benefits from the help of industry partners to 'teach' STEM student future (https://www.techyourfuture.nl/a-955/bridge-the-gap). The PREFER project [13] on Professional Roles and Employability of Future EngineeRs, aims to help engineering students/graduates with identifying their strengths and weaknesses. Additionally, it will to provide them with opportunities to actively explore the wide variety of engineering roles in the labour market. The project will develop a Professional Roles Framework. The Professional Roles Framework will consist of several different roles that engineers can take up in industry. Each role will be clearly defined with an associated set of competencies and skills (http://www.preferproject.eu/). In Italy, LA.R.I.O.S is Research and Intervention Laboratory for Choice Orientation of the University of Padua (http://larios.psy.unipd.it/ze-research.php). It is a working group that offers interventions - which are the result of rigorous research - to students and workers who are interested in counselling activities. The laboratory develops some decision- making skills: analyzing effects of cognitive and non-cognitive variables on decisional styles, increase cognitive and noncognitive dimensions of decision making, development of the effectiveness in the career decision- making.

More globally on decision making skills, the ongoing European DAhoy project with France, Scotland, Spain and Iceland supports the coherent inclusion of active and engaging pedagogical models. It investigates Decision Making as a transversal skill, in association with three complementary dimensions: (i) Math-based Decision Making, with rationality, (ii) Socialbased Decision Making, including people's interdependencies and social identities, and (iii) Career-based Decision Making, to better choose owns career path. Some of its teaching and learning offers on career decision making are presented in the next section.

\section{ACTIVE TEACHING AND LEARNING OFFERS TO PREPARE FUTURE STEM PROFESSIONALS TO AN UNPREDICTABLE FUTURE}

How to reinforce STEM student career decision-making skills, to take good career decisions at right times? Several teaching and learning approaches exist, such as work integrated models, interns, summer jobs, workshops, active sessions, portfolios, company visits, career days, fairs, recruitment assessment workshops, personality tests [14], one2one or group coaching $[15,16]$, meetings, \& conferences, forums, serious games, career games, etc. all along a curriculum. Promoting such learning activities aim to facilitate, reinforce and continuously support self-efficacy and confidence, from new engineering students to future engineers (professional identities), participation in student choices, consistently with aspirations and potential. From the early stages of their STEM studies, they must be encourage to discuss to students career perspectives, to give them a sense of responsibility (their wishes), and enhance their job applications, to allow them to engage actively in their own learning path, plan proactively their future career, and build their future professional identity [3]. 


\subsection{Board games examples for career decision learning}

Card games is a ludic approach for the education pedagogy. The Publishing Trap (https://copyrightliteracy.org/resources/the-publishing-trap/) is a board game from the UK Copyright Literacy team that allows participants to discuss the role of open access in research by following the lives of four researchers - from doctoral research to their academic legacies. The game was developed in the framework of a European project called RRI-Tools (https://www.rri-tools.eu/). This project was developed by a Consortium of 26 partners from 19 European countries that include representatives from a wide range of stakeholders (research, civil society, policy making, education and business) and has received funding from the European Union's Seventh Framework Programme for research, technological development and demonstration.

The game analyses the evolution of the professional career of four characters from the beginning of the career to Professorship. These four characters are different. They study different career specialities: An astrophysicist who studies dark matter and deep space; an English Literature researcher, specialising in the work of Jane Austen; a microbiologist researching environmental factors affecting cell mutations; a criminologist studying gangs in south east London.

The players play with a profile in the board game. Each player must make choices regarding his character in different scenarios. Each player must make decisions about how to disseminate their research at conferences, in academic journals and in monographs. Through playing the game in teams, players get to discuss the impact and the consequences of each character's choices. They will also learn that many pragmatic decisions may need to be made during an academic career and there are trade-offs between academic promotion. The game ends at the end of the character's life, when players see the consequences of the choices they have made in different aspects: money, knowledge, evolution of the professional career or effects between others.

\subsection{A DAhoy card games examples to embrace career decision making skills}

The partners of the DAhoy project conduct research actions, mostly based on a design-based method, to enhance decision making skills of learners. On progress are created and operated card games for students to practice Career Decision Making and benefit from professional project accompaniment, at the time in 2019 at IMT Atlantique (France) and at Reykjavik University (Iceland) [17].

\subsubsection{Self-awareness tooling as a starter}

For innovative teaching \& learning activities in the area of career decision making, one proposed is theoretically founded on the DOTS model to approach a so- called 'jobs casino' (see Figures 2 and 3). This iterative game process starts with a VIA Classification of Strengths which is a "backbone" of the science of positive psychology. In fact, good career decisions could begin with self-knowledge. Self-knowledge can be defined as having a clear and accurate perception of who you are - including your strengths, capabilities, character, feelings, and motivations. It's the foundation on which development is built, both personally and professionally. Self-awareness is also a key to good career decisions. The VIA Survey (http://www.viacharacter.org) is a psychometrically validated personality test that measures an individual's character strengths. Character strengths are viewed as our positive personality in that they are our core capacities for thinking, feeling, and behaving in ways that can bring benefit to us and others. The $24 \mathrm{VIA}$ character strengths are:

- Valued as good

- Improve self without diminishing others

- Able to be nurtured

- Able to be used to describe individual differences

- The Expanded language of self/other knowledge and possibilities

- Help you make decisions 
The use of VIA character strengths permits the player first get a better knowledge of his/her strengths. To unlock the door to self-knowledge, as a basis for making a good career and life choices, an in-depth understanding of personal goals is a precondition: What do I want? What do I want out of life? What kind of life do I envision for myself? What do I want to achieve? What kind of contribution or difference do I want to make? The VIA character test is then followed by the VIA card game.

To be able to make a better decision, different exercises with strength cards can help. If you are a teacher, counsellor or line manager working one-to-one, the Strengths cards are a perfect tool for helping others to identify and explore their strengths so that both you and they have a better understanding of who they are at their best. A great start to building self-awareness and self-confidence. So that individuals may be better able to make a good decision and can use their strengths.

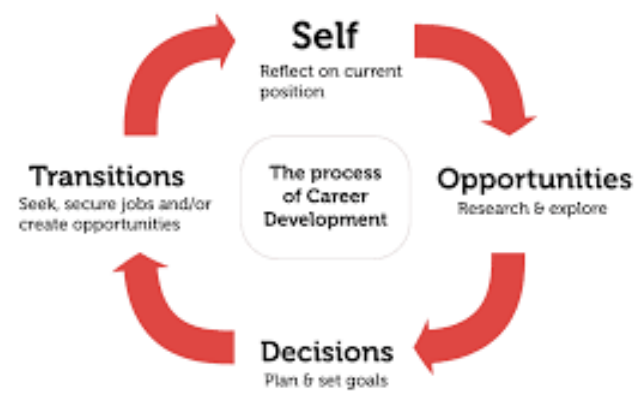

Figure 2. DOTS model developed by Law and Watts

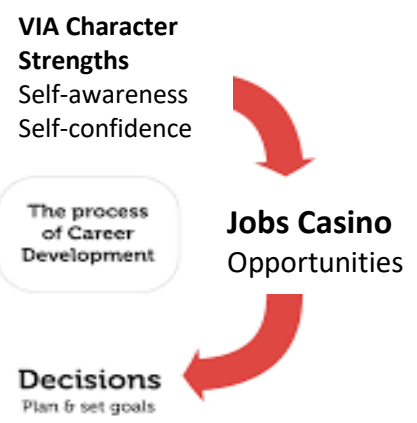

Figure 3. DAhoy DOTS-based card game process

Thanks to group session, Strengths cards can be used in many ways to facilitate individuals giving feedback to each other (cf. Figure 4), to reflect on project successes, to set goals or reflect on team identity.

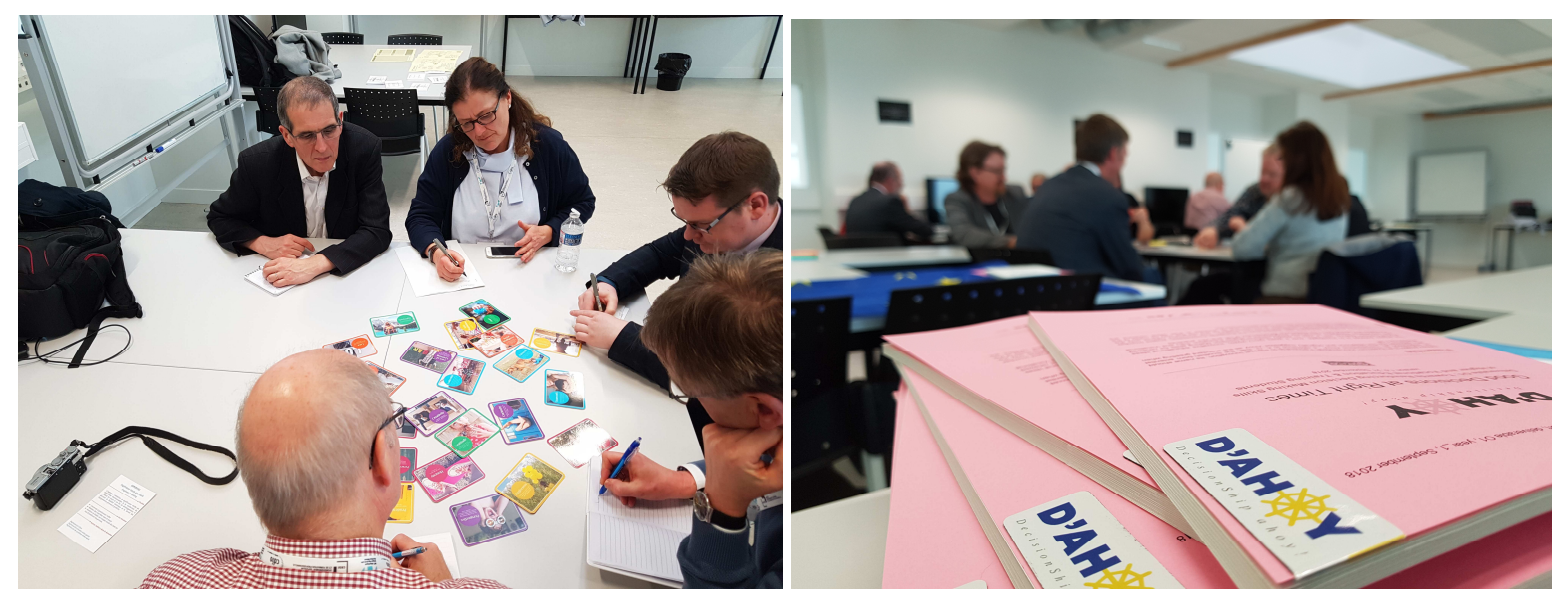

Figure 4. DAhoy Strengths character gamers during the CDIO European Conference, January 2019

\subsection{2 'Casino jobs' with the '6 hats' method of E. De Bono}

A special cards game has been created to make professional scenarios included one job in a domain, with a geographic localisation. The students make their favourite scenario and discuss with the others with the De Bono method; they make alternatives, discuss about the 
consequences (peer learning), take information and plan individual actions. Collaborative and active (cf. Figure 4), this workshop has two advantages: (i) to take the professional decision and (ii) to discover a solving problem method, in a same time. Each student wears one hat with a specific colour. The white hat gives the factual point of view, the yellow hat speaks about the benefits and advantages, the black hut speaks about the difficulties and risks, the green hut shows the opportunities, the red hut is feeling and emotional intelligence, the blue hut is the rational thinking. With this 360 degree vision, the professional project target could be approved or not.

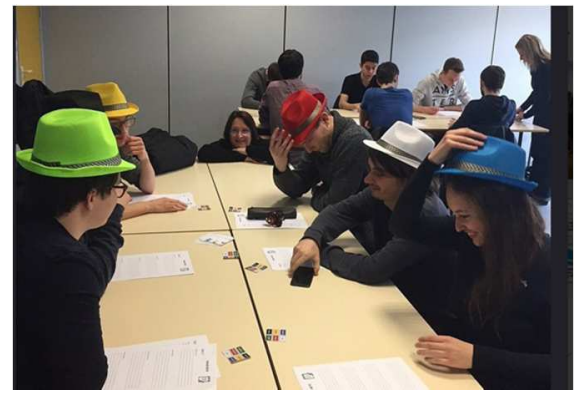

Figure 5. Jobs, activity sectors, localisations and joker to imagine a good to best job.

\subsubsection{Orientation}

As another teaching \& learning activity, a complementary DAhoy card game has been designed and operated. In the iterative DOTS model, it is used as an 'ice breaker' or in order to facilitate to the analysis of a professional scenario, in small groups or on individual coaching. Each card proposes a question (cf. Figure 6). The questions concern gender issues; balance between private/ professional life; criterion of choice for the first job, e.g. position, geographic localisation, company size, responsibilities, autonomy; the package of remuneration; the comprehension of the STEM missions; the difference between: Expert, Manager, Consultant, Entrepreneur; the choice of the company (values); the management style; entrepreneurship; social Atmosphere of company; career mobility, a.s.o. (cf. Figure 7).

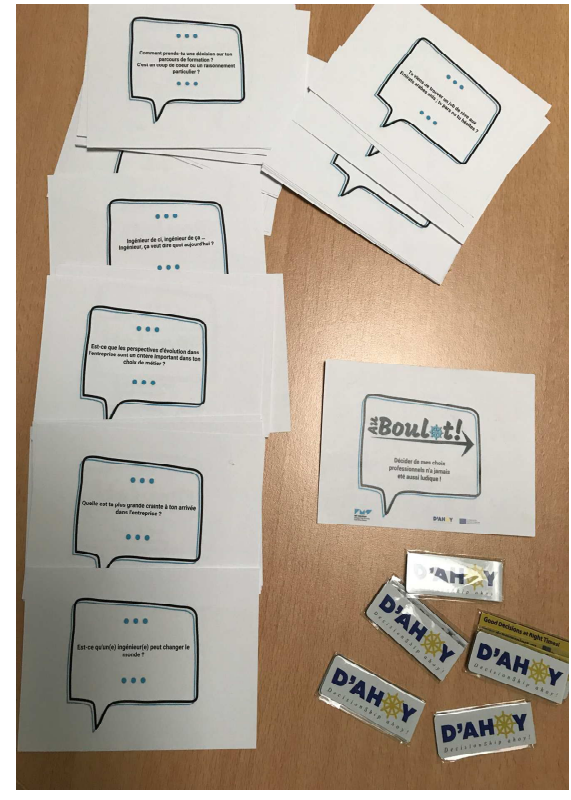

Figure 6. DAhoy 'Au Boulot / 'At Work!' Cards.
- How do you make a decision about your training course? Is it instinct or a particular reasoning?

- Do you think that the position of Consultant is a prestigious / successful job?

- Choose one of these jobs: Expert - Entrepreneur - Consultant Manager and explain why.

- What is the most important criteria for a first job: the location, the sector of activity, the reputation of the company? Why?

- Would you prefer a well-paid job that you moderately enjoy or an exciting job but less well paid?

- Is it easy for you to choose between the jobs accessible with your future degree?

- Would you prefer working in a foreign country or in your own country?

- An efficient search for a first job requires: targeted spontaneous applications, an alumni network, and recommendations from professors. What would be your first choice?

- $\quad$ Did you choose your studies with a particular job in mind?

- Are the evolution perspectives in a company important in your choice of job?

- Is the diversity of tasks important in your choice of job?

- What job did you dream of when you were little?

- Imagine your life in 5 years.

- You win the lottery. Do you continue working?

- Is earning lots of money important to you?

- Would you like to be your own boss, in the future?

- Can an engineer change the world? 


\section{CONCLUSIONS}

The difficulties of decision-making processes in complex or uncertain environments $[18,19]$ can raise contradictions. The complexity associated with the need for rapid decision-making can lead to information overload and impair the decision-makers' judgment [17]. The multicomplexes of criteria, their contradictory aspects, or simply their quantity and ambiguity in a complex situation can even lead to an inability to decide. Mathematical approaches of decision making have their limits when confronted with VUCA variables. This is the VUCA world in context of modern business life, where leaders and managers are tested with fresh challenges of leading innovative teams and individuals in an environment contradicting creation and focus. In teaching the Decision- Making Skills from career construction, we focus on assisting learners plan their life using identity and adaptability. Identity means helping people know their strengths, intentions and their story to shape their choices. The students can make the difference between their vocational belief / influences / fears and become more confident in themselves. And adaptability, knowing how to reflect and revise their choices when the time comes.

We all need to cope with the world we live in today. Integrating theory, research \& practice in career development is of prior importance in STEM education. People play many social roles, and have multiple identities. Rather than being fixed and stable, contemporary identities may be temporary, shifting, and fragmented. Individuals are no longer embedded in contexts that proclaim their identity for life (e.g. an organizational career lasting 30 years). For example, in France 2018, a survey with more than 52000 respondents having an engineer or scientist professional profile [20] recalls that $37 \%$ of French engineers had an international career, with a career very most often linked to opportunities (around 70\%) in various businesses (planned at less than $10 \%$, imposed by the company less than $10 \%$, and imposed by personal events for around $5 \%$ ). In such contexts, individuals need to repeatedly reevaluate and reconstruct their goals, which are viewed as performances rather than as ascribed traits [21]. This paper and the DAhoy project with its innovative teaching \& learning activities are to give the tools and decision skills for such ever changing contexts. On this project, a questionnaire was designed in Spring 2019 and disseminated in May to STEM institutional students in order to analyze and maybe determine how they understand their orientation in the beginning of their STEM studies degree and after the active courses and workshops set up (e.g. 'My life map', 'Casino trades', elective choice, business testimonials, internships). The questions are about their orientation and expectations for a rapidly changing "VUCA world". The survey gives these VUCA characteristics as elements to assess on a four level scale as criteria of appreciation in their ongoing professional project construction.

\section{ACKNOWLEDGEMENTS}

The authors would like to acknowledge their colleagues from the DecisionShip Ahoy project, co-funded by the Erasmus+ programme of the European Union (www.dahoyproject.eu, reference 2017-1-FR01KA203-037301). The European Commission support for the production of this publication does not constitute an endorsement of the contents which reflects the author views only, and the Commission cannot be held responsible for any use which may be made of the information contained therein.

\section{REFERENCES}

[1] Bennett, N. and Lemoine, J., "What VUCA Really Means for You," Harvard Business Review, Vol. 92, No. 1/2, 2014.

[2] R. Karvo, "Career Decision Making," European DAhoy project Youtube channel, 2018, at 1'01, available at https://tinyurl.com/cdm-dahoy

[3] Rouvrais S. and Chelin N., "Engineer Professional Identity: For an Early Clarification of Student's Perceptions," In Electronic Proceedings of the 6th International CDIO Conference, École Polytechnique, Montréal, June 15-18, 2010. 
[4] Gaultier Le Bris, S., Rouvrais, S., Vikingur Fridgeirsson, T., Tudela Villalonga, L., and Waldeck, R., "Decision Making Skills in Engineering Education," in Proceedings of the 45th SEFI 2017 Conference "Education Excellence For Sustainable Development", Terceira Island, Azores, Portugal.18-21 September 2017.

[5] Gerwel Proches C., Chelin N., and Rouvrais S., "Think first job! Preferences and expectations of engineering students in a French 'Grande Ecole'," EJEE European Journal of Engineering Education, Engineering Education Research in Europe - coming of age. Pages 309-325, volume 43, Issue 2, 2018.

[6] B. Coffin and L. Préneron, "Baromètre IPSOS, BCG, CGE : qu'attendent les étudiants et anciens élèves des grandes écoles du marché du travail ?" Boston Consulting Group, IPSOS, and Conference des Grandes Ecoles, January 2018.

[7] R. Amalberti, "Navigating Safety: Necessary Compromises and Trade-Offs - Theory and Practice," Springer, 132 pages, 2013.

[8] J. Holland, "Making Vocational Choices: a theory of careers," Prentice-Hall, 1973.

[9] B. Law and A.G. Watts, "Schools. Careers and Community - A study of some approaches to careers education in schools," London, Career-Learning Network, 1977.

[10] I.L. Janis and L. Mann, "Decision Making," Free Press, 512 pages, 1977.

[11] A. Berglund, "Professionalism for engineers: soft skills in engineering education to prepare for professional life," in Proceedings of the 14th International CDIO Conference, Kanazawa Institute of Technology, Kanazawa, Japan, June 28 -July 2, 2018.

[12] Endedijk, M.D., van Veelen, R., Möwes, R.A., "Not always a nerd: exploring the diversity in professional identity profiles of STEM students in relation to their career choices", Proceedings of the 45th SEFI Conference, pp. 1069-1076. Terceira Island, Portugal, September 2017.

[13] Pinxten, M., Saunders, G., \& Langie, G., "Comparison of 1st year students conceptions on their future roles as engineers between Belgium and The Netherlands", 2018.

[14] Rouvrais, S. and Chelin, N., "Introducing Personality Tests to Clarify Engineering Student Selfperception and Demystify Recruitment Procedures," In Proceedings of the 8th International CDIO Conference, Queensland University of Technology, Brisbane, July 1-4, 2012.

[15] Serreau, Y., "L'entretien d'accompagnement: développement humain et maîtrise des situations dynamiques," In French: Thèse de doctorat en sciences de l'éducation, Bourgogne Franche Comté, France. 2017.

[16] Serreau, Y., "Accompagner la personne en formation - De l'orientation à l'insertion professionnelle". Dunod, 2013.

[17] Rouvrais, S., Gaultier Le Bris, S., and Stewart M. "Engineering Students Ready for a VUCA World? A Design based Research on Decisionship,". in Proceedings of the 14th International CDIO Conference, pages 872--881, KIT, Kanazawa, Japan, June-July, 2018.

[18] Klein, G., "Sources of Power: How People Make Decisions," Boston: The MIT Press. 1999.

[19] Lipshitz, R., Klein, G., Orasanu, J., and Salas, E., "Focus Article: Taking Stock of Naturalistic Decision Making". Journal of Behavioral Decision Making, 14(5), 331-352. 2001.

[20] IESF (Société des Ingénieurs et Scientifiques de France), "23ème Enquête Nationale sur les Ingénieurs 2018", In French. 32 pages, available from www.iesf.fr. 2018.

[21] Savickas, M. L., "Designing projects for career construction". In R. A. Young, J. F. Domene, \& L. Valach (Eds.), Counseling and action: Toward life-enhancing work, relationships, and identity. New York: Springer Science+Business Media, 2015b. 